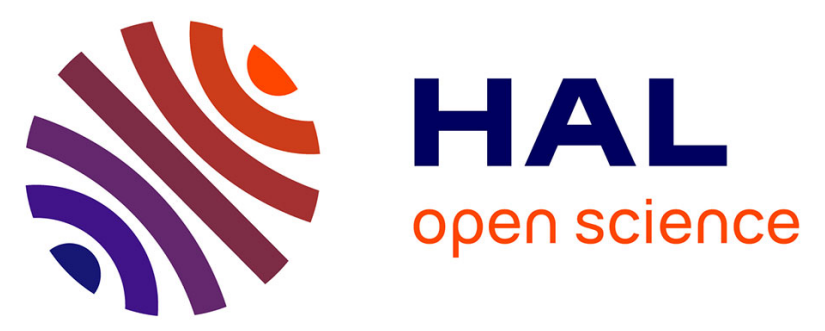

\title{
Investigating the role of root exudates in the interaction between oak seedlings and purple moor grass in temperate forest
}

Marine Fernandez, Philippe Malagoli, Christiane Gallet, Catherine Fernandez, Antoine Vernay, Thierry Ameglio, Philippe Balandier

\section{To cite this version:}

Marine Fernandez, Philippe Malagoli, Christiane Gallet, Catherine Fernandez, Antoine Vernay, et al.. Investigating the role of root exudates in the interaction between oak seedlings and purple moor grass in temperate forest. Forest Ecology and Management, 2021, 491 (119175), 10.1016/j.foreco.2021.119175 . hal-03196931

\section{HAL Id: hal-03196931 \\ https://hal-amu.archives-ouvertes.fr/hal-03196931}

Submitted on 15 Apr 2021

HAL is a multi-disciplinary open access archive for the deposit and dissemination of scientific research documents, whether they are published or not. The documents may come from teaching and research institutions in France or abroad, or from public or private research centers.
L'archive ouverte pluridisciplinaire HAL, est destinée au dépôt et à la diffusion de documents scientifiques de niveau recherche, publiés ou non, émanant des établissements d'enseignement et de recherche français ou étrangers, des laboratoires publics ou privés.

\section{(1) (1) $\$$}

Distributed under a Creative Commons Attribution - NonCommercial - NoDerivatives| 4.0 


\section{Forest Ecology and Management \\ Investigating the role of root exudates in the interaction between oak seedlings and purple moor grass in temperate forest \\ --Manuscript Draft--}

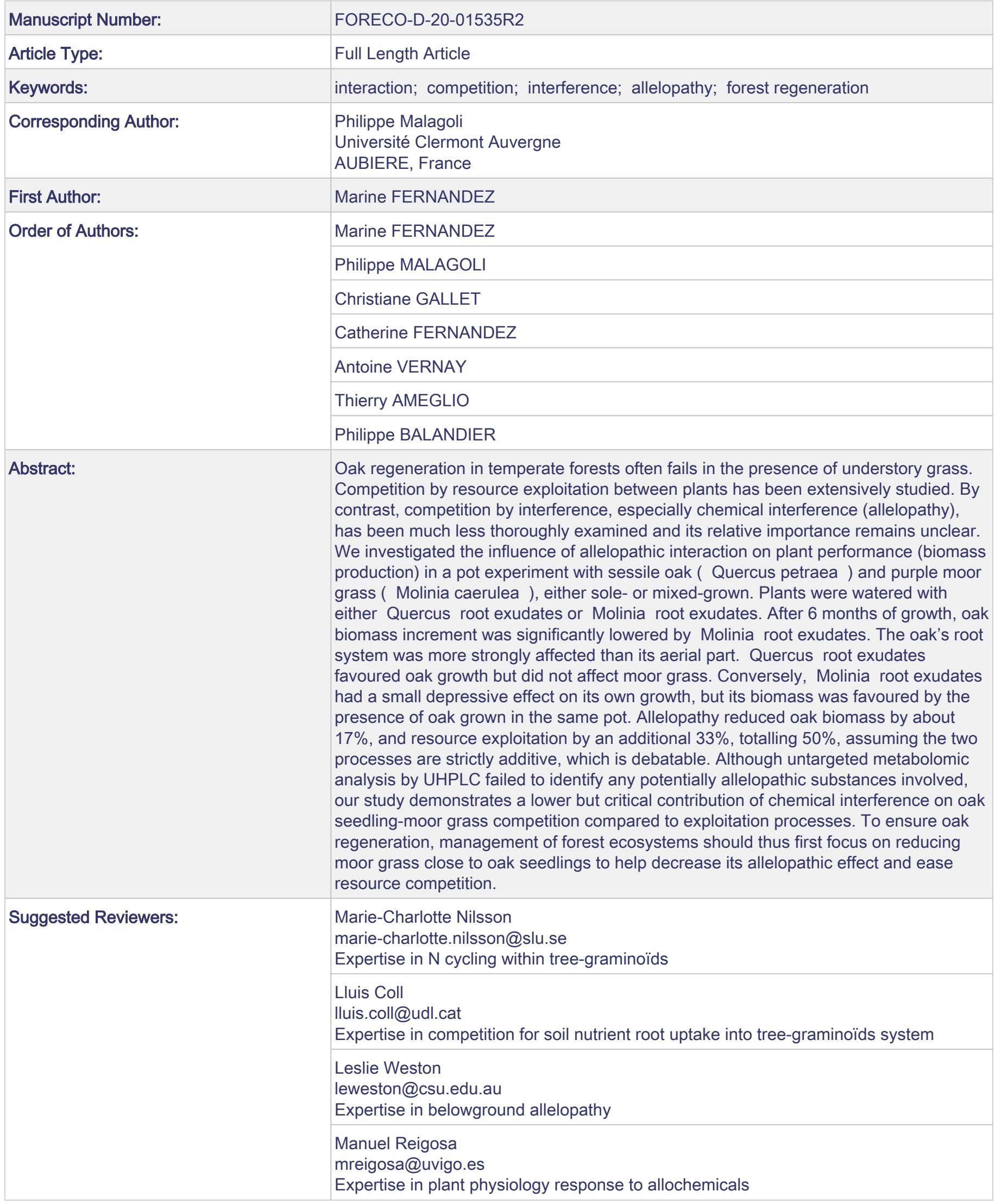




\section{Highlights}

2 - Oak-moor grass interaction also relies on chemical interference

3 - Moor grass roots emit allelopathic compounds reducing oak root growth

4 - Moor grass interference critically contributes to reduce oak growth

5 - Oak regeneration management should first focus on reducing moor grass density 
sessile oak (Quercus petraea) and purple moor grass (Molinia caerulea), either sole- or mixedgrown. Plants were watered with either Quercus root exudates or Molinia root exudates. After 6 months of growth, oak biomass increment was significantly lowered by Molinia root exudates. The oak's root system was more strongly affected than its aerial part. Quercus root exudates favoured oak growth but did not affect moor grass. Conversely, Molinia root exudates had a small depressive effect on its own growth, but its biomass was favoured by the presence of oak grown in the same pot. Resource exploitation had a more detrimental effect than allelopathy and both processes together decreasing oak biomass by 50\%. Although untargeted metabolomic analysis by UHPLC failed to identify any potentially allelopathic substances involved, our study demonstrates a lower but critical contribution of chemical interference on oak seedling-moor grass competition compared to exploitation processes. To ensure oak regeneration, management of forest ecosystems should thus first focus on reducing moor grass close to oak seedlings to help decrease its allelopathic effect and ease resource competition. 


\section{Introduction}

Identifying the balance of processes involved in plant-plant interactions has drawn much attention. Numerous studies have focused on competition for light and soil resources, but the mechanisms involved in soil resource competition (intrinsic root uptake capacity, monitoring of resources uptake dynamic, roles of root exudation, etc.) are seldom investigated, especially in the context of forest tree regeneration. Root competition (intra or inter-specific) has often been described as one of the main interactions driving plant establishment in communities (Casper and Jackson, 1997; Coomes and Grubb, 2000; Schenk, 2006). Two types of root competition have been identified, based on two plant strategies, termed "scramble" and "contest" by Schenk (2006). So far, most studies have focused on "scramble", which is competition by resource exploitation (Grime, 1974; Tilman, 1990; Wilson and Tilman, 1993). This is when two species capture the same resources in the same finite space. Each species then depletes the resource reservoir to the detriment of the other. "Contest", or competition by interference, includes mechanisms by which one species inhibits belowground resource access to another species by active or passive release of chemicals from either roots or shoots. Plant ecologists often use the term allelopathy to describe "contest" competition, but interference also include other non-resource interactions, such as autotoxicity (Guretzky, 2020), space competition (Casper and Jackson, 1997; Schenk, 2006), litter composition and thickness (Foster, 1999; Michalet et al., 2017). Schenk (2006) defines allelopathy narrowly in terms of resource access, but it can include all processes of chemically-mediated interference that alter germination, growth, survival or reproduction (Reigosa et al., 1999; Rice, 1984). Allelochemicals produced by plant organs are released into the environment through (i) release of volatile organic compounds (Effah et al., 2019; Penuelas and Llusia, 1998; Santonja et al., 2019), (ii) decomposition of fallen leaves and needles (Fernandez et al., 2016; Hashoum et al., 2017; Nilsson, 1994), (iii) living root exudates (van Dam and Bouwmeester, 2016), and (iv) decomposition of dead roots (Bertin et al., 2003; Fernandez et al., 2016; Mallik et al., 2016; Tsunoda and van Dam, 2017). Phytotoxic substances in root exudates have been identified in various species such as Secale cereale (Pérez and Ormeno-Nuñez, 1991), Avena fatua (Pérez and Ormeño-Nuñez, 1991), Cucumis sativus (Yu et al., 2003; Yu and Matsui, 1994), Oryza sativa (Kato-Noguchi, 2004), Chenopodium murale (Batish et al., 2007) and Peperomia argyreia (Hao et al., 2010). Allelochemicals can alter neighbouring plant growth and functioning either directly (e.g. by interfering with root system growth and development, root nutrient uptake, or physiological processes) or indirectly through changes in belowground soil 
properties, such as physicochemical conditions (pH, ions availability...) (Huang et al., 2013; Xuan et al., 2005; Zeng, 2014) or soil community diversity, including $\mathrm{N}_{2}$-fixing bacteria and mycorrhizal associations). Seed germination and seedling establishment have been reported as life stages and processes often targeted by allelochemicals (Gallet and Pellissier, 2002). Allelopathy and competition by exploitation can act simultaneously. This makes determining the contributions of the two processes a challenge, especially under field conditions (Fernandez et al., 2016; Nilsson, 1994; Viard-Crétat et al., 2012). Evidence of allelopathic potential can be obtained by removing donor plants or organs, but this is not possible with roots (Fernandez et al., 2016; Fuerst and Putnam, 1983; Inderjit and Mallik, 2002; Olofsdotter et al., 1999; Ridenour and Callaway, 2001).

In most boreal and temperate forests, understorey vegetation has been shown to affect the establishment and growth of tree regeneration (Balandier et al., 2006; Davis et al., 1998; Pagès and Michalet, 2003). Nilsson (1994) sought to separate and quantify contributions of exploitation competition and allelopathic effects of Empetrum hermaphroditum shoots on Scots pine (Pinus sylvestris) seedling growth. These authors pointed out both competition types were involved: E. hermaphroditum led to soil resource depletion but also exerted chemical inhibition on Scots pine seedling growth. Significant studies have been carried out on conifer regeneration failures in the presence of an ericaceous community (Mallik, 2003), underlining the potential role of allelochemicals released by ericaceous species that alter conifer seedling growth (Inderjit and Mallik, 2002, 1996; Mallik et al., 2016). More generally, interactions involving allelopathic substances in woodland have been identified in different tree species regeneration failures (Fisher, 1987) but are still poorly understood, especially in temperate deciduous forests.

Tree seedlings often show significant susceptibility to the presence of herbaceous neighbours. In particular, monopolistic perennial grasses, with a rapid vegetative development and a dense fasciculate root system, rapidly absorb soil resources such as inorganic nitrogen, competing by exploitation to the detriment of tree seedling growth and biomass (Balandier et al., 2006; Coll et al., 2003; Davies, 1987; Vernay et al., 2018a, 2016). At the opposite, with erectophile leaves (angle $\geq 65^{\circ}$, e.g. Balandier et al., 2006), perennial grasses generally induce not so strong competition for light (Gaudio et al., 2011; Picon-Cochard et al., 2006; Vernay et al., 2016). A common case is the regeneration of valuable oak species such as Quercus petraea in temperate forests, which is often jeopardized by the presence of interfering understorey species such as Molinia caerulea, a widespread monopolistic grass (Taylor et al., 2001). For instance, competition by exploitation for N-resources in favour of moor grass was described as 
a major reason for oak regeneration failure (Vernay et al., 2018a, 2018b). However, the respective importance of allelopathy in oak-grass interactions remains to be unravelled (Becker and Lévy, 1982; Timbal et al., 1990). Some studies have demonstrated the allelopathic potential of some oak species ( $Q$. robur, $Q$. pubescens, $Q$. coccifera) exerted both on model and cultivated species (lettuce, wheat, barley, lentil, chickpea, faba bean and flax) and native herbaceous species (Alrababah et al., 2009; Hashoum et al., 2017; Souto et al., 1994). Conversely, Quercus seedling susceptibility to tree allelochemicals has been demonstrated in very few studies (Fernandez et al. 2016; Q. pubescens and Pinus halepensis).

Studies generally focus on "one-way" allelopathic interaction, analysing effects of species A on species B but rarely testing effects of root exudates of species B on A, so that the resultant interaction between the two plants is often inaccurately assessed. Moreover, allelochemicals can have intraspecific allelopathic effects, also called auto-allelopathy or autotoxicity (Böttger et al., 2018; Friedman and Waller, 1985; Singh et al., 1999). Various grasses or crops are known to exert an allelopathic effect on themselves, such as wheat (Wu et al., 2007) or barley (Ben-Hammouda et al., 2002), which can influence the community dynamics. In an interspecific context, it is not known whether Quercus root exudates contain secondary metabolites, in addition to the nitrogen released in the soil, that can improve moor grass growth (Fernandez et al., 2020). Allelopathic potential of root exudates has received much attention but little is known about their facilitative potential (Li et al., 2016). Fernandez et al. (2020) concomitantly observed a negative effect of the presence of moor grass on oak seedling growth and a positive reverse effect largely due to rapid nitrogen transfers from tree seedling to grass. Interactions simultaneously involving both a competition effect of plant A on plant B and a facilitation effect of plant B on plant A are called antagonistic (Michalet et al., 2011; Pistón et al., 2018; Schöb et al., 2014, 2013; Zélé et al., 2018) and have been scantly described.

Based on two complementary experiments, the "two-way" allelopathic interaction between sessile oak seedling and purple moor grass was investigated and extended by a more specific focus on the "one-way" interaction to characterize the allelopathic effect of Molinia exudates on oak seedlings specifically on shoot and root biomass. In the "two-way" experiment, we hypothesized (i) that Molinia root exudates might contain chemicals adverse to oak seedling growth and (ii) oak seedling root exudates might contain chemicals facilitating moor grass growth. We also applied root exudates of Quercus and Molinia on oak and moor grass, respectively, to test inhibitory or facilitative potential in the context of intraspecific interaction. 
Two experiments were conducted in pots under outdoor conditions in Clermont-Ferrand

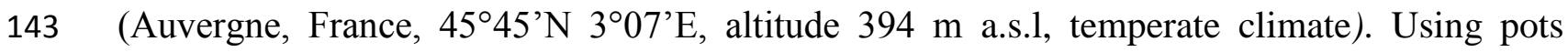
allowed a better controlled irrigation and harvesting of the whole root system. A "two-way" experiment was managed to study both Molinia allelopathic effect on oak seedling and on conspecific Molinia, and the reciprocal, Quercus allelopathic effect on Molinia and conspecific oaks. This was done watering oak or Molinia grown alone with a water solution of root extracts of either oak or Molinia. In this experiment, we also considered the exploitative competition effects on Molinia and Quercus at the plant scale (total biomass), by growing the two species together in a same pot. In a "one-way" experiment, we only tested the allelopathic effect of Molinia on oak growth: here oak's shoot and root compartments were separately measured to focus on oak organs response to interference competition. One-year-old oak seedlings were sourced from a local nursery. Molinia caerulea (L.) Moench was collected in a local forest at Paray-le-Frésil (Auvergne Rhône-Alpes, France; 46³9’N 3³6’E). Oaks and moor grasses were planted in pots filled with natural forest soil (typical luvisol redoxisol pseudogley, sandy loam) collected in the same forest as the moor grasses. To avoid water stress, pots were irrigated to field capacity throughout the experiment. Humidity probes set up in some pots monitored soil water content in the middle of the pot. No fertilizer was added to the pot during the experiment.

\section{“Two-way” experiment (Figure 1A)}

The experiment lasted from March to September 2018. In March 2018, 30 1-year-old bare-root oak seedlings (Quercus petraea (Matt.) Liebl.) and 30 moor grass tufts were planted separately in $5 \mathrm{~L}$ plastic pots or together in $10 \mathrm{~L}$ plastic pots. Oaks were $51.7 \pm 4.0 \mathrm{~cm}$ in height (mean $\pm \mathrm{SE}$ ), and 7.6 $\pm 1.3 \mathrm{~mm}$ in diameter on average. Moor grasses were $10.1 \pm 1.0 \mathrm{~g}$ fresh weight. To prepare solutions of fresh root aqueous maceration, 12 donor oaks and 12 donor moor grasses planted in $5 \mathrm{~L}$ pots were collected at the rate of one plant per week (one solution of root exudate supply per week for 12 weeks). Intact fresh roots were washed, weighed and consistently macerated in distilled water for $48 \mathrm{~h}$ in darkness at room temperature. The concentration of these root exudates was $2 \%$ (root dry weight/water volume), which is the range commonly reported in literature (Fernandez et al., 2006: 2.5 and 5\%; Hashoum et al., 2017: 1 and 2.5\%; Nilsson et al., 1993: 0, 0.5, 1.5, 2.5 and 3.75\%). The final volume of aqueous exudates was split and immediately poured into the pots containing the target oak seedling or moor grass. Concomitantly, sole-growing targets received an equivalent volume of distilled 
water (control). Root exudates of Quercus and Molinia were then applied on soil immediately after maceration. The experimental design was as follows (Fig. 1):

(i) Six recipient oaks and six recipient moor grasses were planted alone in $5 \mathrm{~L}$ pots without addition of root exudates ("sole-grown", SG), they received an equivalent volume of distilled water (control)

(ii) Six sole-growing recipient oaks received Quercus root exudates ("SG + Quercus exudates") and six others received Molinia root exudates ("SG + Molinia exudates"),

(iii) Six sole-growing recipient-moor grasses received Quercus root exudates ("SG + Quercus exudates") and six others received Molinia root exudates ("SG + Molinia exudates"),

(iv) One oak and one moor grass were planted in the same $10 \mathrm{~L}$ pot ("mixed-grown") to analyse competition through physical interaction without addition of root exudates $(n=6)$.

Oak seedlings used in conditions (ii) and (iii) were on average $44.3 \pm 13.6 \mathrm{~g}$ fresh weight. Oaks used in (i) and (iv) were $33.4 \pm 10.5 \mathrm{~g}$ fresh weight. Because of this unintentional initial biomass difference, we could not compare final biomass of shoot and root between the different pot conditions. Alternatively, we compared response in total dry biomass by relative growth increment, i.e. considering the initial difference, in the four experimental conditions. Relative increment (RI) was calculated by the expression (South, 1995):

$$
\mathrm{RI}=\frac{\mathrm{DW}_{\mathrm{F}}-\mathrm{DW}_{\mathrm{I}}}{\mathrm{DW}_{\mathrm{I}}}
$$

where $\mathrm{DW}_{\mathrm{I}}$ was the initial dry weight of oak and moor grass when potting and $\mathrm{DW}_{\mathrm{F}}$ was the final dry weight at harvest.

Plants were harvested in September 2018, i.e. after 6 months of growth. Shoots and roots were collected, washed and dried at $60{ }^{\circ} \mathrm{C}$ for $48 \mathrm{~h}$ before weighing.

\section{One-way experiment (Figure 1B)}

The experiment lasted from April 2017 to August 2017. In April 2017, 16 one-year-old bare-root oak seedlings (Quercus petraea) and 12 moor grass tufts were planted separately in $5 \mathrm{~L}$ plastic pots. In this experiment, moor grasses were used only as 'donors' to produce root exudates, and oaks were only targets. Oaks were $19.9 \pm 6.7 \mathrm{~g}$ (mean $\pm \mathrm{SE}$ ) fresh weight, $40.8 \pm$ $4.2 \mathrm{~cm}$ in height, and $4.9 \pm 0.8 \mathrm{~mm}$ in diameter on average. Moor grasses were $10.3 \pm 1.5 \mathrm{~g}$ fresh weight. In this experiment, special attention was paid to height and weight 
homogenization of oaks to compare shoot and root biomass of controls and Molinia exudate receivers.

One donor moor grass tuft was harvested every week for 12 weeks from June 2017. Root exudates were obtained by the same method as described in the "two-way" experiment. The final volume of aqueous exudates was split weekly and immediately poured into the eight pots containing one target oak seedling each. Concomitantly, eight sole-growing target oak seedlings received an equivalent volume of distilled water (control).

Receiver oak seedlings were harvested in October 2017, i.e. after 6 months of growth. Oak shoots and roots were collected, roots were carefully separated from soil by washing, dried at $60{ }^{\circ} \mathrm{C}$ for $48 \mathrm{~h}$, and weighed. Organ biomass was used as an integrated proxy of oak growth throughout the season.

\section{Data analysis}

Statistical analysis was performed using R software (Version 3.4.1.).

In the two-way experiment, data were means of $n=6$ biological replicates. We used a linear model ( $1 \mathrm{~m}$ function) to determine the response of relative dry biomass increment, the root/shoot (R/S) dry biomass ratio to competition (SG vs MG) and exudate exposure (SG + Quercus exudates, SG + Molinia exudates). A pairwise comparison was then applied to the different treatment combinations to assess the significant differences $(\alpha=0.05)$. Data were tested for normality using the Shapiro-Wilk test and for homoscedasticity using the Levene test before statistical analyses. Data were analysed using one-way ANOVA with Tukey's post hoc test. In the one-way experiment, data were the means of $n=8$ biological replicates. We used a linear model (lm function) to determine the response of oak dry weight and oak relative dry biomass increment to the different pot conditions: SG and SG + Molinia exudates. A $t$ test was used to examine the difference in shoot and root dry weight and RI between "sole-grown" and "SG + Molinia exudates". Here, results were analysed with one level of significance $(\alpha=0.05)$.

\section{Results}

Response of relative biomass increment and root/shoot ratio to root exudate application (twoway experiment)

In the two-way experiment, Molinia root exudates (SG + Molinia exudates) had no significant effect on oak relative dry weight relative increment (RI) in comparison with SG ( $p$ 
$=0.46$, Figure 2A, Tables S1 and S2). Oak biomass was significantly lower in MG than in SG treatment $(p=0.04)$, and SG + Molinia exudate treatment was marginally higher than MG $(p=$ 0.09). Globally, oak RI was ordered SG > SG + Molinia exudates > MG. Application of Quercus root exudates marginally increased oak RI compared to the sole-grown condition ( $p=$ $0.08)$.

For moor grasses, a marginally lower relative dry weight increment was recorded in the presence of its own root exudates compared to control $(p=0.08$, Figure 2B, Tables S1 and S2), whereas neither Quercus root exudates ("SG + Quercus exudates") nor oak physical presence ("mixed-grown") had any effect on Molinia RI. However, a significantly higher Molinia RI was estimated between SG + Molinia exudates and MG $(p=0.04)$.

Oak root/shoot ratio (R/S) was unaffected by application of either root exudate (Figure 3, Table S3 and S4). By contrast, moor grass R/S ratio was dramatically reduced when mixedgrown with oak ( $p=0.02$, Figure 3, Table S3 and S4).

Response of oak root and shoot biomass, relative biomass increment and root/shoot ratio to Molinia root exudate application (one-way experiment)

In the one-way experiment, root dry weight of oak seedlings was significantly lower after weekly supply of Molinia root exudates ( $p=0.03$, Figure 4 and Table S5), whereas shoot dry weight reduction in response to Molinia root exudates was only marginally significant ( $p=$ 0.06, Figure 4 and Table S5). Root dry weight was reduced by $50 \%$ and shoot dry weight by $44 \%$ by Molinia exudates. No significant difference was observed in relative biomass increment (Figure 5 and Table S5) or in R/S ratio (Figure 6 and Table S5).

\section{Discussion}

Our results show that oak-moor grass interactions are more complex than hitherto described. Competition by exploitation is not the only explanation for the deleterious effect of moor grass on oak growth. Molinia root exudates generally had a negative effect on oak growth, especially on roots, suggesting involvement of allelochemicals. Another interesting result was the strong decrease in the moor grass $\mathrm{R} / \mathrm{S}$ ratio in the presence of oak, revealing a change in biomass allocation. A higher biomass allocation in shoot purple moor grass without necessity to invest in the root compartment suggested that oak facilitated grass growth. Conversely, root exudates of Quercus had no significant effect on moor grass but they tended to have a positive intraspecific effect. 
As reported by numerous studies in natural conditions, light competition occurs simultaneously with belowground resource and interference competition. Even if light competition by perennial grasses is often limited as highlighted in the introduction, we recognize that the net outcome of competition in situ would be the integration of light and belowground competition processes. However, the study and the following discussion focused on the allelopathic effect. Accordingly, light competition was removed from the experimental design to understand in more details the belowground allelopathic effect. Our aim was not to reproduce natural conditions but rather to lean on belowground processes. A more suitable design would be necessary to disentangle the combined contribution of light, belowground resource competition and allelopathy in the field.

The two-way experiment showed a consistent lower oak RI when mixed-grown with moor grass, and to a lesser extent after application of Molinia exudate solution. This is consistent with the simultaneous expression of the two types of competition, namely resource exploitation and chemical interference, respectively. When mixed-grown with moor grass, oak underwent both processes, whereas when sole-grown and watered with the Molinia exudate solution, oak was subjected only to allelopathic effects. On the assumption, which remains to be thoroughly tested, that effects of interference and competition by resource exploitation do not interact and can be distinguished from each other (Inderjit and Callaway, 2003; Inderjit and Del Moral, 1997; Uddin and Robinson, 2017; Weidenhamer, 2006), the difference between oak SG, SG + Molinia exudates and MG gave the relative contributions of the two competition types. Mixed-grown oak RI showed a 50\% decrease compared to sole-grown, whereas allelopathy (SG + Molinia exudates) was responsible for a $17 \%$ decrease, although not statistically significant. Considering that allelopathy and resource competition are independent of each other, have additive effects, and the nature and quantity of root exudates were the same than in maceration, this means that resource competition could be responsible for about a $50 \%-17 \%=33 \%$ decrease. This result suggested that in our pot experiment, resource exploitation had a greater effect than the allelopathic pathway. These results were consistent with other studies working on interactions between $P$. sylvestris and E. hermaphroditum (Nilsson et al., 1993) or between Q. pubescens and P. halepensis (Fernandez et al., 2016). They demonstrated that $P$. sylvestris and $Q$. pubescens biomass were more strongly reduced by a combination of allelopathy and competition than allelopathy alone. Moreover, treatments altered biomass allocation of Quercus pubescens with a lower R/S ratio in the case of allelopathy (Fernandez et al., 2016). Our results did not support this effect, oak R/S being non- 
significantly affected by the treatment although the root system was more strongly altered than the shoot system, probably owing to a high variability of responses.

\section{Root exudates of oak favour its own growth, but exudates of Molinia inhibit its own growth}

Quercus root exudates tended to favour oak biomass but had no effect on moor grass biomass. This result was surprising because previous studies using different species compositions demonstrated a facilitating effect in interspecific interactions and not in intraspecific interactions. For example, Li et al. (2016) evidenced that root exudates of maize promoted $\mathrm{N}_{2}$ fixation of faba bean (Vicia faba L.), whereas to our knowledge, whether root exudates can facilitate growth of conspecific species is still not known. Further studies should analyse the effects of species physical presence on the nature and intensity of root exudates rather than root exudates of sole-grown species. By contrast, in the present study, moor grass biomass was not significantly affected by Quercus root exudates. This is at variance with some studies reporting an allelopathic effect of Quercus sp from different regions on understorey species (Li et al., 2007). Callaway et al. (1991) identified an allelopathic property of adult Quercus root exudates that inhibited understorey productivity in woodlands. Alrababah et al. (2009) and Hashoum et al. (2017) demonstrated that aqueous extract of green and senescent mature $Q$. coccifera and $Q$. pubescens leaves and litter contained allelochemicals that reduced seed germination and controlled the dynamics of the herbaceous species. In our study, we were interested in the regeneration phase of the oak. At this stage young seedlings are characterized by small below- and aboveground biomasses, making them more vulnerable to grass understorey, and their allelochemical profile is probably different from that of a mature tree. Molinia own root exudates tended to decrease its total relative dry weight increment. Autoallelopathy is a recognised mechanism in various plant species (Jamshidi et al., 2011; Mafeo and Mashela, 2010; Yu et al., 2003) that can lead to community stability by tempering the establishment of a single species. Specificity and intensity of plant interactions seem difficult to predict and probably depend on the species and on its biotic and abiotic environment.

As reported elsewhere (Vernay et al., 2018a, 2018b) grass dry weight was higher when mixed-grown with oak, although the difference was marginally significant in the present study. The most remarkable effect was recorded on the moor grass R/S ratio in the mixed-grown condition, which was significantly lower. Preferential biomass allocation to shoots can be interpreted as a strategy of a fast-growing species associated with a need to meet its $\mathrm{C}$ requirements when $\mathrm{N}$ availability allows it (Mardanov et al., 1998). Sufficient $\mathrm{N}$ availability 
could be attributed to oak rhizodeposition, which provided nitrogen and facilitates moor grass shoot growth (Fernandez et al., 2020).

\section{Molinia root exudates inhibit oak growth}

Biomass analysis in our "one-way" experiment suggested that Molinia root exudates might contain chemicals that inhibit oak seedling growth. Biomass analysis of both root and shoot highlighted that Molinia root exudates had a greater effect on oak roots than shoots, as also observed in Nilsson's study (1994). This decrease was also observed in the relative total dry weight increment and R/S ratio, though not significantly, probably because of wide variabilities. However, the allelopathy effect on oak revealed a temporal variability, decreased growth appearing more marginal in our "two-way experiment" in 2018 than in our "one-way experiment" in 2017.

The one-way experiment focusing specifically on each organ allowed a better understanding of the action mechanisms of Molinia root exudates: inhibiting oak root growth, root exudates participated in strengthening competition for resources in favour of moor grass. Such inhibition of the oak root system is likely to have a negative impact on shoot growth in the following spring.

Zhang et al. (2020) demonstrated through a recent meta-analysis that allelopathy can reduce plant performance by $25 \%$ on average. In the "one-way" experiment, oak shoot and root biomasses were diminished by $47 \%$ and 50\%, respectively, with Molinia root exudates. RI was reduced by $31 \%$ in the "one-way" experiment and to a lesser extent by $17 \%$ in the "two-way" experiment. Also, R/S ratio was decreased by $9.7 \%$ and $3.8 \%$ in the "one-way" and "two-way" experiments, respectively. In our study, we observed an annual variability of the reducing effect and a different intensity of the allelopathic effect in the considered organ. However, the mean of all these reductions due to allelopathy was $26 \%$, which lies in the value range reviewed by Zhang et al. (2020)

\section{Nature of root exudates}

No specialized metabolite was evidenced in the aqueous exudates, although the difference in chemical composition of Molinia and Quercus was confirmed (Figure S1). To our knowledge, studies on root exudates are rare, as extraction from root extracts obtained after root grinding are commonly favoured. However, this did not account for what was actually released by the roots, since all root substances were supplied, including those that would not necessarily 
be released into the soil. Root exudates were obtained by an artificial method (maceration) giving a proxy of root exudates, but this is a reliable method if root exudates could not be extracted from the soil (Oburger and Jones, 2018).

Despite a low concentration of root exudates in the analysed solution, continuous supply interestingly resulted in an inhibition of growth in oak along the monitored period. This striking result suggested a strong allelopathic effect of Molinia roots (SG + Molinia exudates). Moreover, the swift response suggested that allelochemicals likely originated from root exudation by moor grass roots rather than from release by moor grass root decomposition.

\section{Perspectives}

Overall, it is noteworthy that different chemicals originating from root aqueous maceration of different species can have positive or negative effects depending on that species and on the target species. Contrasting effects of root exudates of Quercus and Molinia on each other highlighted the absolute necessity to consider the "two-way" analysis in plant interactions, as well as the intraspecific interactions. Our experiment was conducted in pots so that we could test such effects in vivo. Although many substances are present in the root exudates, we did not identify them in this study. Whereas untargeted metabolomics has been successfully applied to profile root exudates of several species (van Dam and Bouwmeester, 2016), only very few compounds were identified (often less than 10\%) and most of these were primary compounds (such as sugars or amino acids). Identifying specialized compounds in our root exudates would require a comprehensive study focused on the composition of exudates, needing a combination of platforms to succeed. Substances indicated by statistical analysis could be further identified, either by applying MS/MS on peaks in the extract, or by isolating the substance for additional structural analysis using NMR (Oburger and Jones, 2018; van Dam and Bouwmeester, 2016).

Another important point to consider are soil altering allelopathic effect via modifications of biotic and abiotic soil parameters. Root exudates are known to influence nutrient availability and physicochemical soil conditions and reciprocally (Mohammadkhani and Servati, 2018; Zeng, 2014). By altering the soil properties, it is possible that moor grass allelochemicals may had indirectly affected oak growth. We could not exclude this effect, but results suggested that moor grass exudate supply to SG moor grass did not significantly reduce moor grass RI.

Our study highlights the important role of interference processes in oak-grass interaction. Further research should pursue the characterization of the nature and quantity of 
exudates (Oburger and Jones, 2018), given their critical role in plant-plant interaction dynamics (Ehlers et al., 2020).

From a forest management perspective, and specifically in relation to sessile oak regeneration, this study confirms that forest perennial grasses are detrimental to seedling establishment. The allelopathic pathway is one of the processes involved in this inhibition but it seems less important than competition by resource exploitation during the period of growth. Nevertheless, production of allelochemicals contributes to reduced oak performance (growth, soil exploration, efficiency in nutrient acquisition), accentuating competition for resources. Targets of allelopathic substances could be microbial communities associated with oak roots including mycorrhizae, but extensive studies are still needed to address this question. The density and proximity of moor grass around young oak should be reduced by various means to avoid allelopathic effects, which will also reduce resource exploitation. One solution would be to act on light availability in the understorey to modulate the presence and intensity of the competitive processes of moor grass (Gaudio et al., 2011). The decoupling of exploitation $v s$ interference interaction may not be straightforward (Inderjit and Del Moral, 1997) and the potential indirect facilitative effect (Michalet et al., 2015; Siemann and Rogers, 2003) from mature trees could increase resource availability for seedlings and mitigate the production of allelopathic substances from understorey species.

\section{Acknowledgements}

UHPLC-MS was performed on the IMBE Support Service on Chemical Ecology and Metabolomics (funded by the CNRS, the Provence Alpes Côte d'Azur Region, the TOTAL Foundation and ANR) particularly the MALLABAR platform. The authors thank Stéphane Greff for its valuable help in metabolite extraction and chemical analyses of root exudates. 


\section{Appendix 1}

\section{Metabolite extraction}

Molinia root exudate composition was determined with an UHPLC instrument (Dionex Ultimate 3000 equipped with an RS Pump, an autosampler, a thermostated column compartment and a UV diode array, Thermo Scientific, USA) coupled to an accurate mass spectrometer (qToF) equipped with an ESI source (Impact II, Bruker Daltonics, Germany). UHPLC separation was done on an Acclaim C18 column $(2.1 \mathrm{~mm} \times 150 \mathrm{~mm}, 2.2 \mu \mathrm{m}$, Thermo Scientific, USA). Elution rate was set to $0.5 \mathrm{~mL} \mathrm{~min}^{-1}$ at a constant temperature of $45^{\circ} \mathrm{C}$. A pooled sample combining $10 \mu \mathrm{L}$ of each sample was used to determine the chromatographic method and the injection volume. This pooled sample was also used as a quality control.

Injection was set to $10 \mu \mathrm{L}$ after twofold dilution of all exudates with the same solvent as that used for extraction. Chromatographic solvents were composed of A: water with $0.1 \%$ formic acid and B: acetonitrile with the same additive. The chromatographic gradient was set as follows: $2 \%$ of $\mathrm{B}$ for $2 \mathrm{~min}$, then increase in the proportion of solvent $\mathrm{B}$ to reach $100 \%$ at 14 min. Each analysis was followed by a column cleaning phase with $100 \%$ B for 3 min, and column equilibration for $3 \mathrm{~min}$, giving a total runtime of $20 \mathrm{~min}$. Samples of each condition were randomly injected to integrate time-dependent changes in UHPLC-MS chromatographic fingerprints. Pooled samples, injected at the beginning, at the end and every six samples, were used for ion intensity normalization. Blanks were also injected to remove background signals.

MS parameters were set as follows: nebulizer gas, $\mathrm{N}_{2}$ at $51 \mathrm{psi}$; dry gas, $\mathrm{N}_{2}$ at $12 \mathrm{~L} \mathrm{~min}^{-1}$, capillary temperature $200^{\circ} \mathrm{C}$ and voltage $3000 \mathrm{~V}$. The mass spectrometer was systematically calibrated with formate/acetate solution forming clusters on the studied mass range before a full set of analyses. The same calibration solution was automatically injected before each sample for internal mass calibration. For the mass spectra, tests were performed in both negative and positive modes. Mass spectra were in negative ionization mode in full scan mode from 50 to $1200 \mathrm{amu}$ at $2 \mathrm{~Hz}$. DDA-MS2 analyses were performed on three major ions detected at each scan on a pooled sample for metabolite annotation.

\section{Root exudates}

Analyses were automatically recalibrated using internal calibration, ensuring a precision of $\mathrm{m} / \mathrm{z}$ below 2 ppm on the mass range, before exporting data in netCDF files (centroid mode) using Bruker Compass DataAnalysis 4.3. Analysis files were then processed using the XCMS 
447 package (Smith et al. 2006) of R software, using the different steps necessary to generate the 448 final data matrix: (i) peak picking for detection of different features, (ii) retention time 449 correction ("obiwarp" method), (iii) grouping, (iv) filling of peaks to integrate portions where 450 peaks were initially absent and (v) report and data matrix generation transferral to Excel. Each 451 individual ion of each analysis was then normalized according to the injection order as 452 described by Van Der Kloet et al. (2009). After the data set normalization, around 6000 features 453 were kept before the filtering steps. To ensure data quality and remove redundant signals, three 454 successive filtering steps were applied to pre-processed data using an in-house script on $\mathrm{R}$. The 455 first was based on the signal/noise $(\mathrm{S} / \mathrm{N})$ ratio to remove signals observed in blanks $(\mathrm{S} / \mathrm{N}$ set at 45610 for features matching between pooled samples and blanks). The second allowed suppression 457 of signals based on the value of the coefficient of variation of ion intensities in pooled samples 458 (threshold at 0.4 ). The last step consisted in the deletion of all auto-correlated ions (threshold 459 at 0.8 ) to remove isotopes and adducts. 
Alrababah, M.A., Tadros, M.J., Samarah, N.H., Ghosheh, H., 2009. Allelopathic effects of Pinus halepensis and Quercus coccifera on the germination of Mediterranean crop seeds. New For. 38, 261-272. https://doi.org/10.1007/s11056-009-9145-8

Balandier, P., Collet, C., Miller, J.H., Reynolds, P.E., Zedaker, S.M., 2006. Designing forest vegetation management strategies based on the mechanisms and dynamics of crop tree competition by neighbouring vegetation. Forestry 79, 3-27. https://doi.org/10.1093/forestry/cpi056

Batish, D.R., Lavanya, K., Pal Singh, H., Kohli, R.K., 2007. Root-mediated allelopathic interference of nettle-leaved goosefoot (Chenopodium murale) on wheat (Triticum aestivum). J. Agron. Crop Sci. 193, 37-44. https://doi.org/10.1111/j.1439037X.2006.00243.X

Becker, M., Lévy, G., 1982. Le dépérissement du chêne en forêt de Tronçais : les causes écologiques. Ann. des Sci. For. 39, 439-444.

Ben-Hammouda, M., Ghorbal, H., Kremer, R.J., Oueslatt, O., 2002. Autotoxicity of barley. J. Plant Nutr. 25, 1155-1161. https://doi.org/10.1081/PLN-120004379

Bertin, C., Yang, X., Weston, L.A., 2003. The role of root exudates and allelochemicals in the rhizosphere. Plant Soil 256, 67-83. https://doi.org/10.1023/A:1026290508166

Böttger, A., Vothknecht, U., Bolle, C., Wolf, A., 2018. Plant secondary metabolites and their general function in plants, in: Lessons on Caffeine, Cannabis \& Co. pp. 3-17. https://doi.org/10.1007/978-3-319-99546-5

Callaway, R.M., Nadkarni, N.M., Mahall, B.E., 1991. Facilitation and interference of Quercus Douglasii on understory productivity in Central California. Ecology 72, 1484-1499.

Casper, B.B., Jackson, R.B., 1997. Plant competition underground. Annu. Rev. Ecol. Syst. 28, 545-570. https://doi.org/10.1146/annurev.ecolsys.28.1.545

Coll, L., Balandier, P., Picon-Cochard, C., Prévosto, B., Curt, T., 2003. Competition for water between beech seedlings and surrounding vegetation in different light and vegetation composition conditions. Ann. For. Sci 60, 593-600. https://doi.org/10.1051/forest:2003051

Coomes, D.A., Grubb, P.J., 2000. Impacts of root competition in forests and woodlands: a theoretical framework and review of experiments. Ecol. Monogr. 70, 171-207.

Davies, D.A., 1987. Long-term effects of improvement methods on Molinia caerulea dominant rough grazing on wet hill land. 2. Mineral composition of herbage and soil physical, chemical and biological characteristics. J. Agric. Sci. 109, 243. https://doi.org/10.1017/S0021859600080655

Davis, M.A., Wrage, K.J., Reich, P.B., 1998. Competition between tree seedlings and herbaceous vegetation: support for a theory of resource supply and demand. J. Ecol. 86, 652-661. https://doi.org/10.1046/j.1365-2745.1998.00087.x

Effah, E., Holopainen, J.K., McCormick, A.C., 2019. Potential roles of volatile organic compounds in plant competition. Perspect. Plant Ecol. Evol. Syst. 38, 58-63. https://doi.org/10.1016/j.ppees.2019.04.003 
Ehlers, B.K., Berg, M.P., Staudt, M., Holmstrup, M., Glasius, M., Ellers, J., Tomiolo, S., Madsen, R.B., Slotsbo, S., Penuelas, J., 2020. Plant Secondary Compounds in Soil and Their Role in Belowground Species Interactions. Trends Ecol. Evol. 35, 716-730. https://doi.org/10.1016/j.tree.2020.04.001

Fernandez, C., Lelong, B., Vila, B., Mévy, J.P., Robles, C., Greff, S., Dupouyet, S., BousquetMélou, A., 2006. Potential allelopathic effect of Pinus halepensis in the secondary succession: an experimental approach. Chemoecology 16, 97-105. https://doi.org/10.1007/s00049-006-0334-z

Fernandez, C., Monnier, Y., Santonja, M., Gallet, C., Weston, L.A., Prévosto, B., Saunier, A., Baldy, V., Bousquet-Mélou, A., 2016. The impact of competition and allelopathy on the trade-off between plant defense and growth in two contrasting tree species. Front. Plant Sci. 7, 1-14. https://doi.org/10.3389/fpls.2016.00594

Fernandez, M., Malagoli, P., Vernay, A., Améglio, T., Balandier, P., 2020. Below-ground nitrogen transfer from oak seedlings facilitates Molinia growth: ${ }^{15} \mathrm{~N}$ pulse-chase labelling. Plant Soil 449, 343-356. https://doi.org/10.1007/s11104-020-04473-9

Fisher, R.F., 1987. Allelopathy: a potential cause of forest regeneration failure. Allelochem. Role Agric. For. 176-184. https://doi.org/doi:10.1021/bk-1987-0330.ch016

Foster, B.L., 1999. Establishment, competition and the distribution of native grasses among Michigan old-fields. J. Ecol. 87, 476-489.

Friedman, J., Waller, G.R., 1985. Allelopathy and autotoxicity. Trends Biochem. Sci. 10, 47 50. https://doi.org/10.1016/0968-0004(85)90224-5

Fuerst, E.P., Putnam, A.R., 1983. Separating the competitive and allelopathic components of interference - Theoretical principes. J. Chem. Ecol. 9, 937-944. https://doi.org/10.1007/BF00982203

Gallet, C., Pellissier, F., 2002. Interactions allélopathiques en milieu forestier. Rev. For. Française 6, 567-576.

Gaudio, N., Balandier, P., Philippe, G., Dumas, Y., Jean, F., Ginisty, C., 2011. Lightmediated influence of three understorey species (Calluna vulgaris, Pteridium aquilinum, Molinia caerulea) on the growth of Pinus sylvestris seedlings. Eur. J. For. Res. 130, $77-$ 89. https://doi.org/10.1007/s10342-010-0403-2

Grime, J.P., 1974. Vegetation classification by reference to strategies. Nature 250, 26-31. https://doi.org/10.1038/252497a0

Guretzky, J.A., 2020. Plant Interactions, in: Forages: The Science of Grassland Agriculture. pp. $187-199$.

Hao, W., Ren, L., Ran, W., Shen, Q.R., 2010. Allelopathic effects of root exudates from watermelon and rice plants on Fusarium oxysporum f.sp. niveum. Plant Soil 336, 485497. https://doi.org/10.1007/s11104-010-0505-0

Hashoum, H., Santonja, M., Gauquelin, T., Saatkamp, A., Gavinet, J., Greff, S., Lecareux, C., Fernandez, C., Bousquet-Mélou, A., 2017. Biotic interactions in a Mediterranean oak forest: role of allelopathy along phenological development of woody species. Eur. J. For. Res. 136, 699-710. https://doi.org/10.1007/s10342-017-1066-z

Huang, L., Song, L., Xia, X., 2013. Plant-soil feedbacks and soil sickness: from mechanisms 
to application in agriculture. J. Chem. Ecol. 39, 232-242.

https://doi.org/10.1007/s10886-013-0244-9

Inderjit, Callaway, R.M., 2003. Experimental designs for the study of allelopathy. Plant Soil 256, 1-11. https://doi.org/10.1023/A:1026242418333

Inderjit, Del Moral, R., 1997. Is separating resource competition from allelopathy realistic? Bot. Rev. 63, 221-230. https://doi.org/10.1007/BF02857949

Inderjit, Mallik, A.., 2002. Can Kalmia angustifolia interference to black spruce (Picea mariana) be explained by allelopathy? For. Ecol. Manage. 160, 75-84. https://doi.org/10.1016/S0378-1127(01)00463-7

Inderjit, Mallik, A.U., 1996. The nature of interference potential of Kalmia angustifolia. Can. J. For. Res. 26, 1899-1904.

Jamshidi, S., Hashemizadeh, S., Shahrokhi, S., 2011. Assessment of auto-allelopatic potential of broomcorn (Sorghum vulgare var. technicum) 13, 2-6.

Kato-Noguchi, H., 2004. Allelopathic substance in rice root exudates: Rediscovery of momilactone B as an allelochemical. J. Plant Physiol. 161, 271-276. https://doi.org/10.1078/0176-1617-01188

Li, B., Yu-Ying, L., Wu, H.-M., Zhang, F.-F., Li, C.-J., Li, X.-X., Lambers, H., Li, L., 2016. Root exudates drive interspecific facilitation by enhancing nodulation and $\mathrm{N}_{2}$ fixation. Proc. Natl. Acad. Sci. 113, 6496-6501. https://doi.org/10.1073/pnas.1523580113

Li, G. De, Jia, L.M., Li, X.W., 2007. Research advances in allelopathy of Quercus L. For. Stud. China 9, 287-294. https://doi.org/10.1007/s11632-007-0046-7

Mafeo, T.P., Mashela, P.W., 2010. Allelopathic inhibition of seedling emergence in dicotyledonous crops by Cucumis bio-nematicide. African J. Biotechnol. 9, 8349-8354. https://doi.org/10.5897/AJB10.652

Mallik, A.U., 2003. Conifer regeneration problems in boreal and temperate forests with ericaceous understory: role of disturbance, seedbed limitation, and keytsone species change. CRC. Crit. Rev. Plant Sci. 22, 341-366.

Mallik, A.U., Biswas, S.R.;, Collier, L.C.S., 2016. Belowground interactions between Kalmia angustifolia and Picea mariana: roles of competition, root exudates and ectomycorrhizal association. Plant Soil 403, 471-483. https://doi.org/10.1007/s11104-016-2819-z

Mardanov, A., Samedovam, A., Shirvany, T., 1998. Root-shoot relationships in plant adaptation to nitrogen deficiency $147-154$.

Michalet, R., Chen, S.Y., An, L.Z., Wang, X.T., Wang, Y.X., Guo, P., Ding, C.C., Xiao, S., 2015. Communities: are they groups of hidden interactions? J. Veg. Sci. 26, 1-12. https://doi.org/10.1111/jvs.12226

Michalet, R., Maalouf, J., Hayek, P. Al, 2017. Direct litter interference and indirect soil competitive effects of two contrasting phenotypes of a spiny legume shrub drive the forb composition of an oromediterranean community. Oikos 126, 1090-1100. https://doi.org/10.1111/oik.03800

Michalet, R., Xiao, S., Cavieres, L.A., Ragan, M., 2011. Phenotypic variation in nurse traits and community feedbacks define an alpine community. Ecol. Lett. 14, 433-443. https://doi.org/10.1111/j.1461-0248.2011.01605.x 
Mohammadkhani, N., Servati, M., 2018. Nutrient concentration in wheat and soil under allelopathy treatments. J. Plant Res. 131, 143-155. https://doi.org/10.1007/s10265-0170981-x

Nilsson, M.-C., Högberg, P., Zackrisson, O., Fengyou, W., 1993. Allelopathic effects by Empetrum hermaphroditum on development and nitrogen uptake by roots and mycorrhizae of Pinus silvestris. Can. J. Bot. 71, 620-628. https://doi.org/10.1139/b93071

Nilsson, M.C., 1994. Separation of allelopathy and resource competition by the boreal dwarf shrub Empetrum hermaphroditum Hagerup. Oecologia 98, 1-7. https://doi.org/10.1007/BF00326083

Oburger, E., Jones, D.L., 2018. Sampling root exudates - Mission impossible? Rhizosphere 6, 116-133. https://doi.org/10.1016/j.rhisph.2018.06.004

Olofsdotter, M., Navarez, D., Rebulanan, M., Streibig, J.C., 1999. Weed-suppressing rice cultivars - Does allelopathy play a role? Weed Res. 39, 441-454. https://doi.org/10.1046/j.1365-3180.1999.00159.x

Pagès, J.-P., Michalet, R., 2003. A test of the indirect facilitation model in a temperate hardwood forest of the Northern French Alps. J. Ecol. 91, 932-940.

Penuelas, J., Llusia, J., 1998. Influence of intra- and inter-specific interference on terpene emission by Pinus halepensis and Quercus ilex seedlings. Biol. Plant. 41, 139-143.

Pérez, F.J., Ormeno-Nuñez, J., 1991. Difference in hydroxamic acid content in roots and root exudates of wheat (Triticum aestivum L.) and rye (Secale cereale L.): Possible role in allelopathy. J. Chem. Ecol. 17, 1037-1043. https://doi.org/10.1007/BF01402932

Pérez, F.J., Ormeño-Nuñez, J., 1991. Root exudates of wild oats: allelopathic effect on spring wheat. Phytochemistry 30, 2199-2202. https://doi.org/10.1016/0031-9422(91)83614-Q

Picon-Cochard, C., Coll, L., Balandier, P., 2006. The role of below-ground competition during early stages of secondary succession: the case of 3-year-old Scots pine (Pinus sylvestris L.) seedlings in an abandoned grassland. Oecologia 148, 373-383. https://doi.org/10.1007/s00442-006-0379-2

Pistón, N., Michalet, R., Schöb, C., Macek, P., Armas, C., Pugnaire, F.I., 2018. The balance of canopy and soil effects determines intraspecific differences in foundation species' effects on associated plants. Funct. Ecol. 32, 2253-2263. https://doi.org/10.1111/13652435.13139

Reigosa, M.J., Sánchez-moreiras, A., González, L., 1999. Ecophysiological approach in allelopathy. Crit. Rev. Biotechnol. 18, 577-608. https://doi.org/10.1080/07352689991309405

Rice, E.L., 1984. Allelopathy, in: Rice, E.L. (Ed.), . Academic Press, Orlando. https://doi.org/https://doi.org/10.1016/B978-0-08-092539-4.50019-8

Ridenour, W.M., Callaway, R.M., 2001. The relative importance of allelopathy in interference: the effects of an invasive weed on a native bunchgrass. Oecologia 126, 444-450. https://doi.org/10.1007/s004420000533

Santonja, M., Bousquet- Mélou, A., Greff, S., Ormeño, E., Fernandez, C., 2019. Allelopathic effects of volatile organic compounds released from Pinus halepensis needles and roots. 
Ecol. Evol. 8201-8213. https://doi.org/10.1002/ece3.5390

Schenk, H.J., 2006. Root competition: beyond resource depletion. J. Ecol. https://doi.org/10.1111/j.1365-2745.2006.01124.x

Schöb, C., Callaway, R.M., Anthelme, F., Brooker, R.W., Cavieres, L.A., Kikvidze, Z., Lortie, C.J., Michalet, R., Pugnaire, F.I., Xiao, S., Cranston, B.H., García, M.C., Hupp, N.R., Llambí, L.D., Lingua, E., Reid, A.M., Zhao, L., Butterfield, B.J., 2014. The context dependence of beneficiary feedback effects on benefactors in plant facilitation. $\mathrm{J}$. Physiol. 204, 386-396. https://doi.org/10.1111/nph.12908

Schöb, C., Prieto, I., Armas, C., Pugnaire, F.I., 2013. Consequences of facilitation: one plant's benefit is another plant's cost. Funct. Ecol. 28, 500-508. https://doi.org/10.1111/13652435.12185

Siemann, E., Rogers, W.E., 2003. Changes in light and nitrogen availability under pioneer trees may indirectly facilitate tree invasions of grasslands. J. Ecol. 91, 923-931. https://doi.org/10.1046/j.1365-2745.2003.00822.x

Singh, H.P., Batish, D.R., Kohli, R.K., 1999. Autotoxicity: Concept, Organisms, and Ecological Significance. CRC. Crit. Rev. Plant Sci. 18, 757-772. https://doi.org/10.1080/07352689991309478

South, D.B., 1995. Relative Growth Rate: a critique. South African For. J. 173, 1-6.

Souto, X.C., Gonzales, L., Reigosa, M.J., 1994. Comparative analysis of allelopathic effects produced by four forestry species during decomposition process in their soils in Galicia (NW Spain). J. Chem. Ecol. 20, 3005-3015. https://doi.org/10.1007/BF02098405

Taylor, K., Rowland, A.P., Jones, H.E., 2001. Molinia caerulea (L.) Moench. J. Ecol. 89, 126-144. https://doi.org/10.1046/j.1365-2745.2001.00534.x

Tilman, D., 1990. Constraints and tradeoffs: toward a predictive theory of competition and succession. Oikos 58, 3-15. https://doi.org/10.2307/3565355

Timbal, J., Gelpe, J., Garbaye, J., Courrier, G., 1990. Étude préliminaire sur l'effet dépressif de la molinie (Molinia caerulea) sur la croissance et l'état mycorhizien de semis de chêne rouge (Quercus rubra). Ann. For. Sci. 21, 643-649.

Tsunoda, T., van Dam, N.M., 2017. Root chemical traits and their roles in belowground biotic interactions. Pedobiologia (Jena). 65, 58-67. https://doi.org/10.1016/j.pedobi.2017.05.007

Uddin, M.N., Robinson, R.W., 2017. Allelopathy and resource competition: the effects of Phragmites australis invasion in plant communities. Bot. Stud. 58. https://doi.org/10.1186/s40529-017-0183-9

van Dam, N.M., Bouwmeester, H.J., 2016. Metabolomics in the Rhizosphere: Tapping into Belowground Chemical Communication. Trends Plant Sci. 21, 256-265. https://doi.org/10.1016/j.tplants.2016.01.008

Vernay, A., Balandier, P., Guinard, L., Améglio, T., Malagoli, P., 2016. Photosynthesis capacity of Quercus petraea (Matt.) saplings is affected by Molinia caerulea (L.) under high irradiance. For. Ecol. Manage. 376, 107-117. https://doi.org/10.1016/j.foreco.2016.05.045 
Improved Deschampsia cespitosa growth by nitrogen fertilization jeopardizes Quercus petraea regeneration through intensification of competition. Basic Appl. Ecol. 31, 21-32. https://doi.org/10.1016/j.baae.2018.06.002

Vernay, A., Malagoli, P., Fernandez, M., Perot, T., Améglio, T., Balandier, P., 2018b. Carryover benefit of high internal N pool on growth and function of oak seedlings (Quercus petraea) competing with Deschampsia cespitosa. For. Ecol. Manage. 419-420, 130-138. https://doi.org/10.1016/j.foreco.2018.03.039

Viard-Crétat, F., Baptist, F., Secher-Fromell, H., Gallet, C., 2012. The allelopathic effects of Festuca paniculata depend on competition in subalpine grasslands. Plant Ecol. 213, 1963-1973. https://doi.org/10.1007/s11258-012-0143-0

Weidenhamer, J.D., 2006. Distinguishing allelopathy from resource competition: The role of density. Allelopath. A Physiol. Process with Ecol. Implic. 85-103. https://doi.org/10.1007/1-4020-4280-9_4

Wilson, S.D., Tilman, D., 1993. Plant competition and resource availability in response to disturbance and fertilization. Ecology 74, 599-611.

Wu, H., Pratley, J., Lemerle, D., An, M., Liu, D.L., 2007. Autotoxicity of wheat (Triticum aestivum L.) as determined by laboratory bioassays. Plant Soil 296, 85-93. https://doi.org/10.1007/s11104-007-9292-7

Xuan, T.D., Tawata, S., Khanh, T.D., Chung, I.M., 2005. Decomposition of allelopathic plants in soil. J. Agron. Crop Sci. 191, 162-171.

Yu, J.Q., Matsui, Y., 1994. Phytotoxic substances in root exudates of cucumber (Cucumis sativus L.). J. Chem. Ecol. 20, 21-31. https://doi.org/10.1007/BF02065988

Yu, J.Q., Ye, S.F., Zhang, M.F., Hu, W.H., 2003. Effects of root exudates and aqueous root extracts of cucumber (Cucumis sativus) and allelochemicals, on photosynthesis and antioxidant enzymes in cucumber. Biochem. Syst. Ecol. 31, 129-139. https://doi.org/10.1016/S0305-1978(02)00150-3

Zélé, F., Magalhães, S., Kéfi, S., Duncan, A.B., 2018. Ecology and evolution of facilitation among symbionts. Nat. Commun. 9, 1-12. https://doi.org/10.1038/s41467-018-06779-w

Zeng, R. Sen, 2014. Allelopathy - The solution is indirect. J. Chem. Ecol. 40, 515-516. https://doi.org/10.1007/s10886-014-0464-7

Zhang, Z., Liu, Y., Yuan, L., Weber, E., van Kleunen, M., 2020. Effect of allelopathy on plant performance: a meta-analysis. Ecol. Lett. https://doi.org/10.1111/ele.13627 
Figure 1. Experimental design of "two-way" experiment (A) and "one-way" experiment (B) with the different treatments tested on oak seedlings and Molinia tufts: sole-grown (SG), SG + Quercus exudates, SG + Molinia exudates, and mixed-grown (competition by exploitation + allelopathy).

Figure 2. Oak (a) and purple moor grass (b) relative dry biomass increment in the "two-way" experiment for the four different treatments: sole-grown (white bars), SG + Quercus exudates (light blue bars), SG + Molinia exudates (blue bars) and mixed-grown (dark blue bars). Values are reported as means \pm SE (standard error, $n=6$ ). Different letters indicate a significant difference between treatments.

Figure 3. Oak (a) and purple moor grass (b) root/shoot dry biomass ratio in the "two-way" experiment for the four different treatments: sole-grown (white bars), $\mathrm{SG}+$ Quercus exudates (light blue bars), SG + Molinia exudates (blue bars) and mixed-grown (dark blue bars). Values are reported as means \pm SE $(n=6)$. Different letters indicate a significant difference between treatments.

Figure 4. Above- and belowground dry weights (g) of oak in the "one-way" experiment for the two different treatments: sole-grown (white bars) and SG + Molinia exudates (blue bars). Values are reported as means $\pm \mathrm{SE}(n=8)$. * corresponds to $p<0.05$.

Figure 5. Oak relative dry biomass increment in the "one-way" experiment for the two different treatments: sole-grown (white bars) and SG + Molinia exudates (blue bars). Values are reported as means $\pm \operatorname{SE}(n=8)$.

Figure 6. Oak root/shoot dry biomass ratio in the "one-way" experiment for the two different treatments: sole-grown (white bars) and SG + Molinia exudates (blue bars). Values are reported as means $\pm \operatorname{SE}(n=8)$. 
727 Appendix

728

729 


\section{Statistical tables}

\section{Abbreviations}

Ctrl Control

ME Molinia root exudates

OE Oak root exudates

Comp Competition (exploitation competition + allelopathy)

Table S1. (Figure 2). Means \pm SE of oak and moor grass relative dry biomass increment (two-way experiment) in sole-grown (SG), Quercus root exudates (SG + Quercus exudates), Molinia root exudates $(\mathrm{SG}+$ Molinia exudates) and mixed-grown (MG) treatment $(n=6)$.

\begin{tabular}{ccccc|cccc}
\hline & \multicolumn{4}{c|}{ Oak } & \multicolumn{4}{c}{ Molinia } \\
& $\mathrm{SG}$ & $\mathrm{SG}+Q$ & $\mathrm{SG}+M$ & $\mathrm{MG}$ & $\mathrm{SG}$ & $\mathrm{SG}+Q$ & $\mathrm{SG}+M$ & $\mathrm{MG}$ \\
\hline \multirow{2}{*}{ Mean $\pm \mathrm{SE}$} & $1.71 \pm$ & $3.06 \pm$ & $1.42 \pm$ & $0.85 \pm$ & $30.47 \pm$ & $28.94 \pm$ & $23.54 \pm$ & $34.37 \pm$ \\
& 0.29 & 0.60 & 0.24 & 0.19 & 2.23 & 5.25 & 2.68 & 3.68 \\
\hline
\end{tabular}

Table S2. (Figure 2). Test statistic ( $F$-value), statistical significance ( $p$-value), and degrees of freedom (DF) assessing the effect of treatment on oak and moor grass relative dry biomass increment $(n=6)$.

\begin{tabular}{|c|c|c|c|c|c|c|c|}
\hline & & $\begin{array}{c}\text { SG- } \\
\mathrm{SG}+Q\end{array}$ & $\begin{array}{c}\mathrm{SG}- \\
\mathrm{SG}+M\end{array}$ & $\begin{array}{l}\text { SG- } \\
\text { MG }\end{array}$ & $\begin{array}{l}\mathrm{SG}+Q- \\
\mathrm{SG}+M\end{array}$ & $\begin{array}{c}\mathrm{SG}+Q^{-} \\
\mathrm{MG}\end{array}$ & $\begin{array}{c}\mathrm{SG}+M- \\
\mathrm{MG}\end{array}$ \\
\hline Oak & $\begin{array}{c}p \text {-value } \\
F \text {-stat } \\
\text { DF }\end{array}$ & 0.08 & 0.46 & 0.04 & 0.04 & 0.01 & 0.09 \\
\hline Molinia & $\begin{array}{c}p \text {-value } \\
F \text {-stat } \\
\text { DF }\end{array}$ & 0.79 & 0.08 & 0.39 & 0.38 & 0.42 & 0.04 \\
\hline
\end{tabular}

Table S3. (Figure 3). Means $\pm \mathrm{SE}$ of oak and moor grass R/S ratio (two-way experiment) in sole-grown (SG), Quercus root exudates $(\mathrm{SG}+Q)$, Molinia root exudates $(\mathrm{SG}+M)$ and mixed-grown $(\mathrm{MG})$ treatment $(n=6)$.

\begin{tabular}{ccccc|cccc}
\hline & \multicolumn{4}{c|}{ Oak } & \multicolumn{4}{c}{ Purple moor grass } \\
& $\mathrm{SG}$ & $\mathrm{SG}+Q$ & $\mathrm{SG}+M$ & $\mathrm{MG}$ & $\mathrm{SG}$ & $\mathrm{SG}+Q$ & $\mathrm{SG}+M$ & $\mathrm{MG}$ \\
\hline \multirow{2}{*}{ Mean $\pm \mathrm{SE}$} & $0.80 \pm$ & $0.94 \pm$ & $0.77 \pm$ & $0.86 \pm$ & $1.58 \pm$ & $1.70 \pm$ & $1.64 \pm$ & $0.45 \pm$ \\
& 0.09 & 0.06 & 0.09 & 0.14 & 0.33 & 0.56 & 0.39 & 0.06 \\
\hline
\end{tabular}

Table S4. (Figure 3). Test statistic ( $F$-value), statistical significance ( $p$-value), and degrees of freedom (DF) assessing the effect of treatment on oak and moor grass $\mathrm{R} / \mathrm{S}$ ratio $(n=6)$.

\begin{tabular}{|c|c|c|c|c|c|c|c|}
\hline & & $\begin{array}{c}\mathrm{SG}- \\
\mathrm{SG}+Q\end{array}$ & $\begin{array}{c}\mathrm{SG}- \\
\mathrm{SG}+M\end{array}$ & $\begin{array}{l}\text { SG- } \\
\text { MG }\end{array}$ & $\begin{array}{l}\mathrm{SG}+Q- \\
\mathrm{SG}+M\end{array}$ & $\begin{array}{c}\mathrm{SG}+Q- \\
\mathrm{MG}\end{array}$ & $\begin{array}{c}\mathrm{SG}+M- \\
\mathrm{MG}\end{array}$ \\
\hline Oak & $\begin{array}{c}p \text {-value } \\
F \text {-stat } \\
\text { DF }\end{array}$ & 0.22 & 0.80 & 0.72 & 0.13 & 0.59 & 0.58 \\
\hline Molinia & $\begin{array}{c}p \text {-value } \\
F \text {-stat } \\
\text { DF }\end{array}$ & 0.86 & 0.91 & 0.02 & 0.93 & 0.07 & 0.02 \\
\hline
\end{tabular}


Table S5. (Figure 4, 5 and 6). Means $\pm \mathrm{SE}$ (g) of oak shoot and root dry weight (one-way experiment) in sole-grown (SG) and Molinia root exudates $(\mathrm{SG}+M)$ treatment. Test statistic ( $t$-value), statistical significance ( $p$-value), and degrees of freedom (DF) assessing the effect of treatment on shoot and root dry weight of oak $(n=8)$.

\begin{tabular}{|c|c|c|c|c|}
\hline & & Biomass & Relative increment & Root/shoot ratio \\
\hline & & $\mathrm{SG}+M$ & $\mathrm{SG}+M$ & $\mathrm{SG}+M$ \\
\hline Shoot & $\begin{array}{l}\text { Mean } \\
p \text {-value } \\
t \text {-value } \\
\text { DF }\end{array}$ & $\begin{array}{c}16.36 \pm 2.78 \quad 9.37 \pm 1.79 \\
0.06 \\
-2.11 \\
10.22 \\
\end{array}$ & $\begin{array}{c}3.34 \pm 1.58 \quad 2.29 \pm 1.31 \\
0.17 \\
1.44 \\
13.54\end{array}$ & $\begin{array}{c}1.75 \pm 016 \quad 1.58 \pm 0.09 \\
0.35 \\
-0.98 \\
9.39\end{array}$ \\
\hline Root & $\begin{array}{l}\text { Mean } \\
p \text {-value } \\
t \text {-value } \\
\text { DF }\end{array}$ & $\begin{array}{c}28.84 \pm 4.84 \quad 14.48 \pm 2.43 \\
0.03 \\
-2.65 \\
8.84\end{array}$ & & \\
\hline
\end{tabular}


(a) Two-way experiment

Sole-grown (SG)

Oak

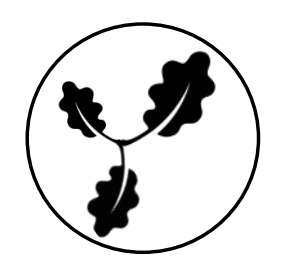

$n=6$

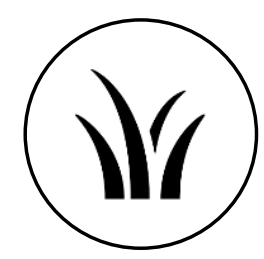

$n=6$
SG oak exudates
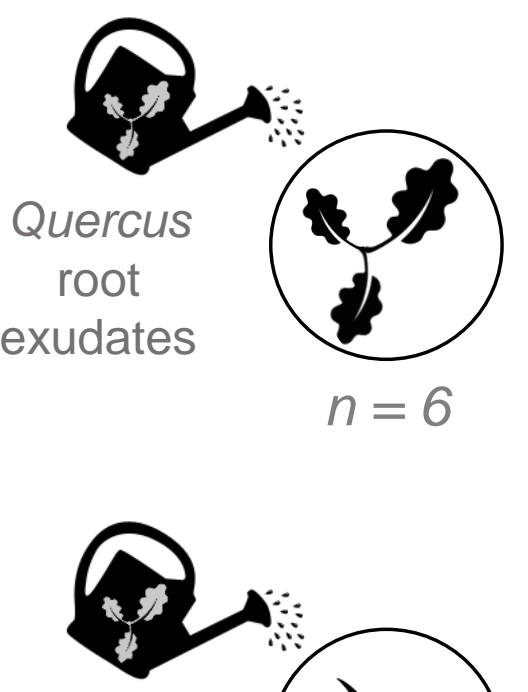

Quercus root exudates

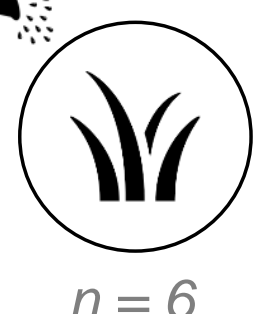

$n=6$
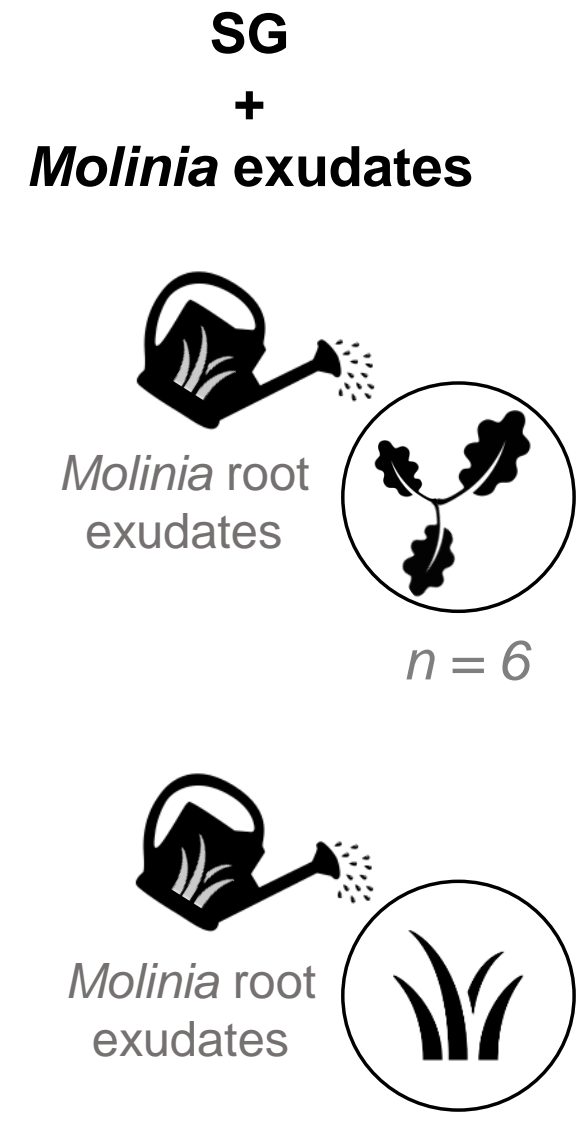

Mixed-grown (MG)

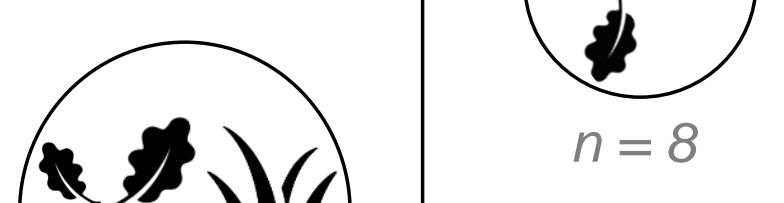

(b) One-way experiment

Sole-grown exudates

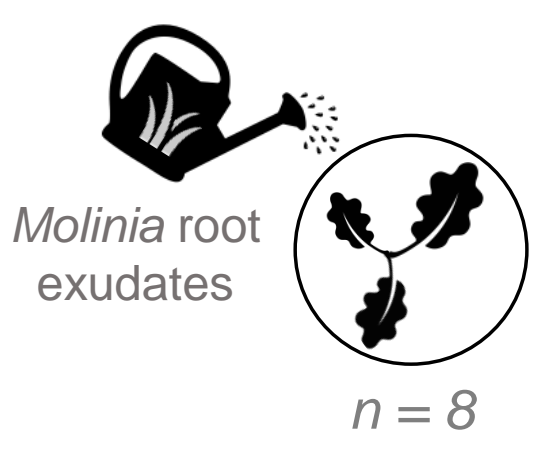

$n=6$ 

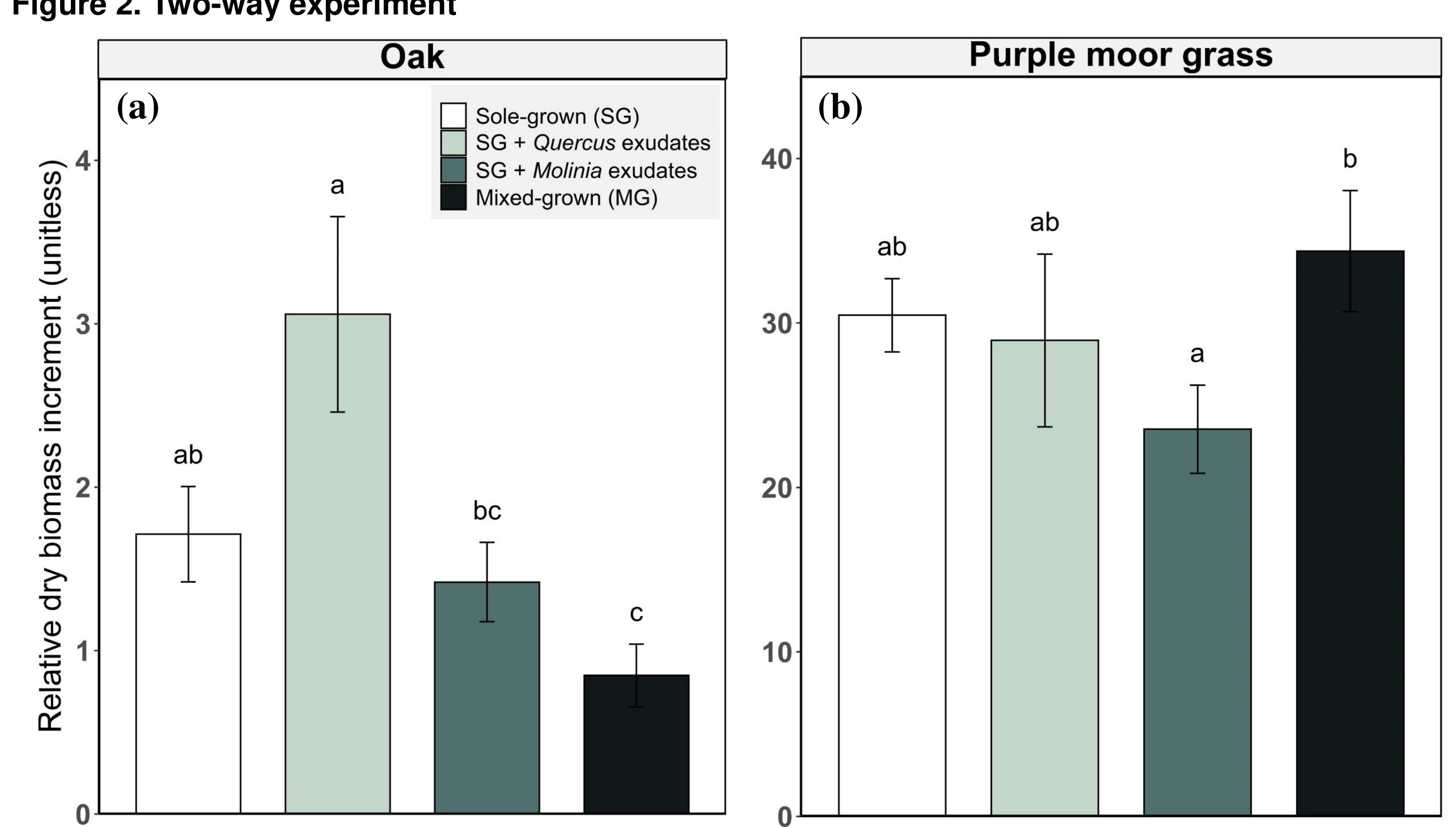

Figure 2. Two-way experiment

(b)

\section{Purple moor grass}


Figure 3. Two-way experiment
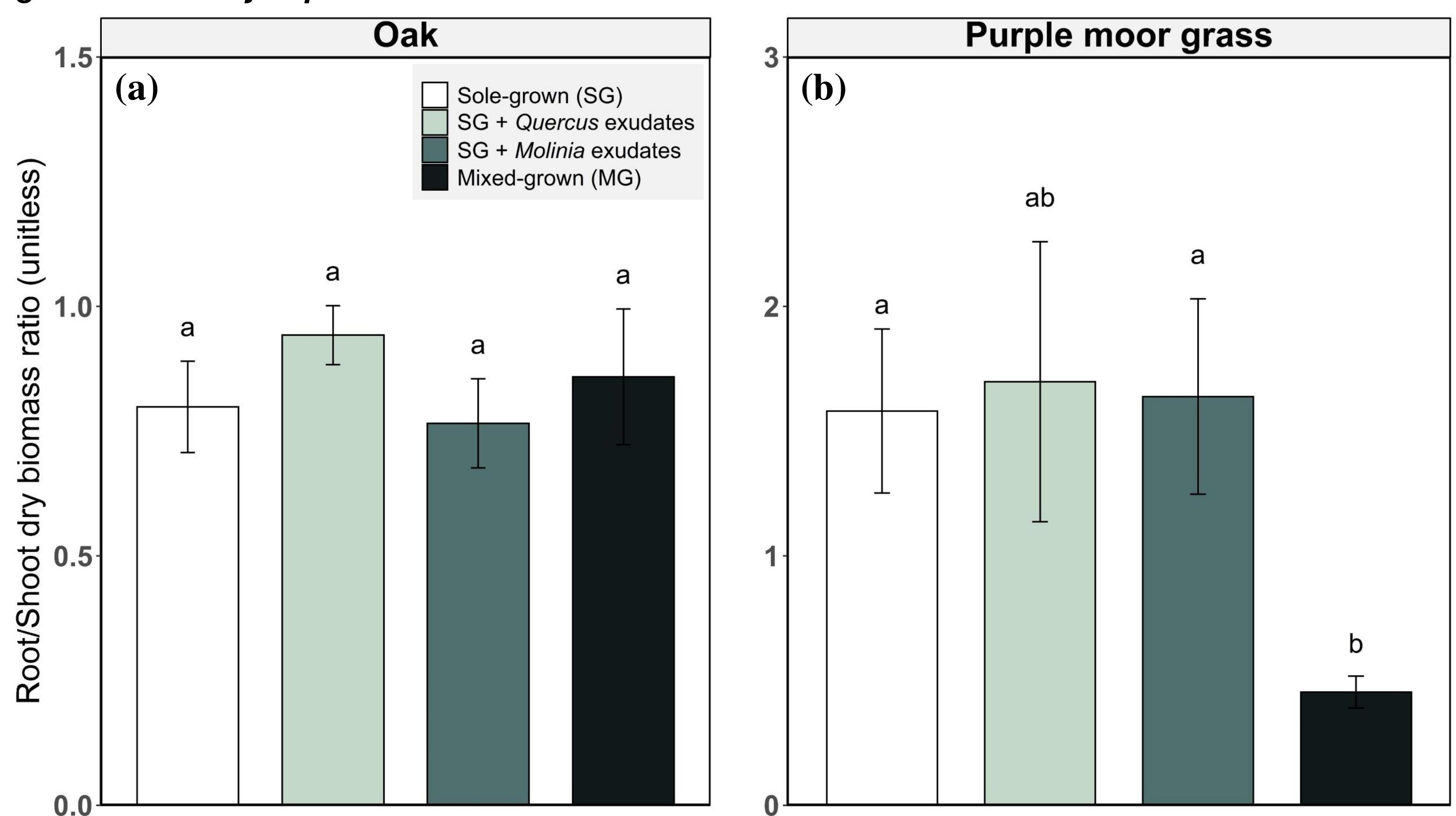
Figure 4. One-way experiment

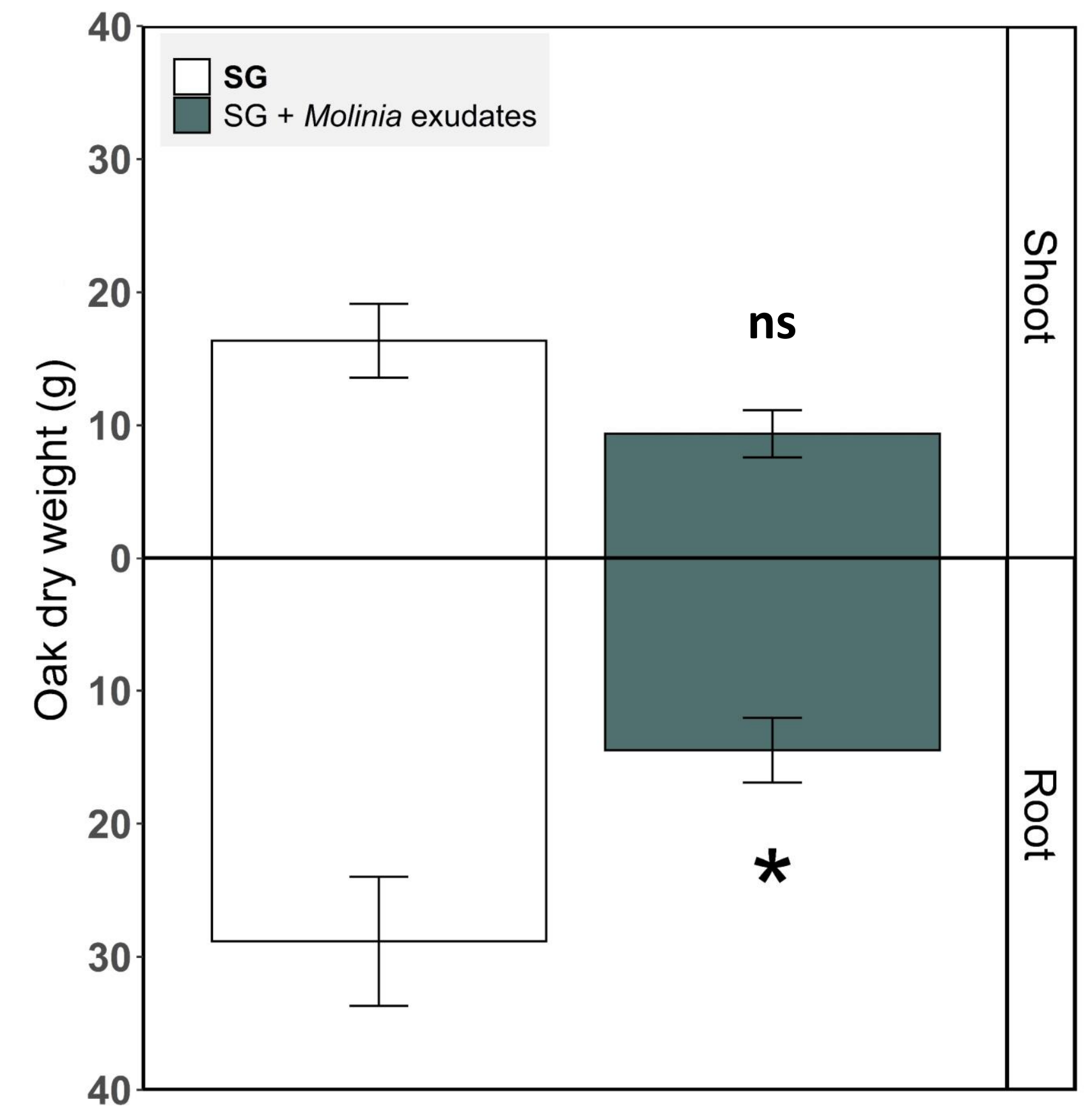


Figure 5.

One-way experiment

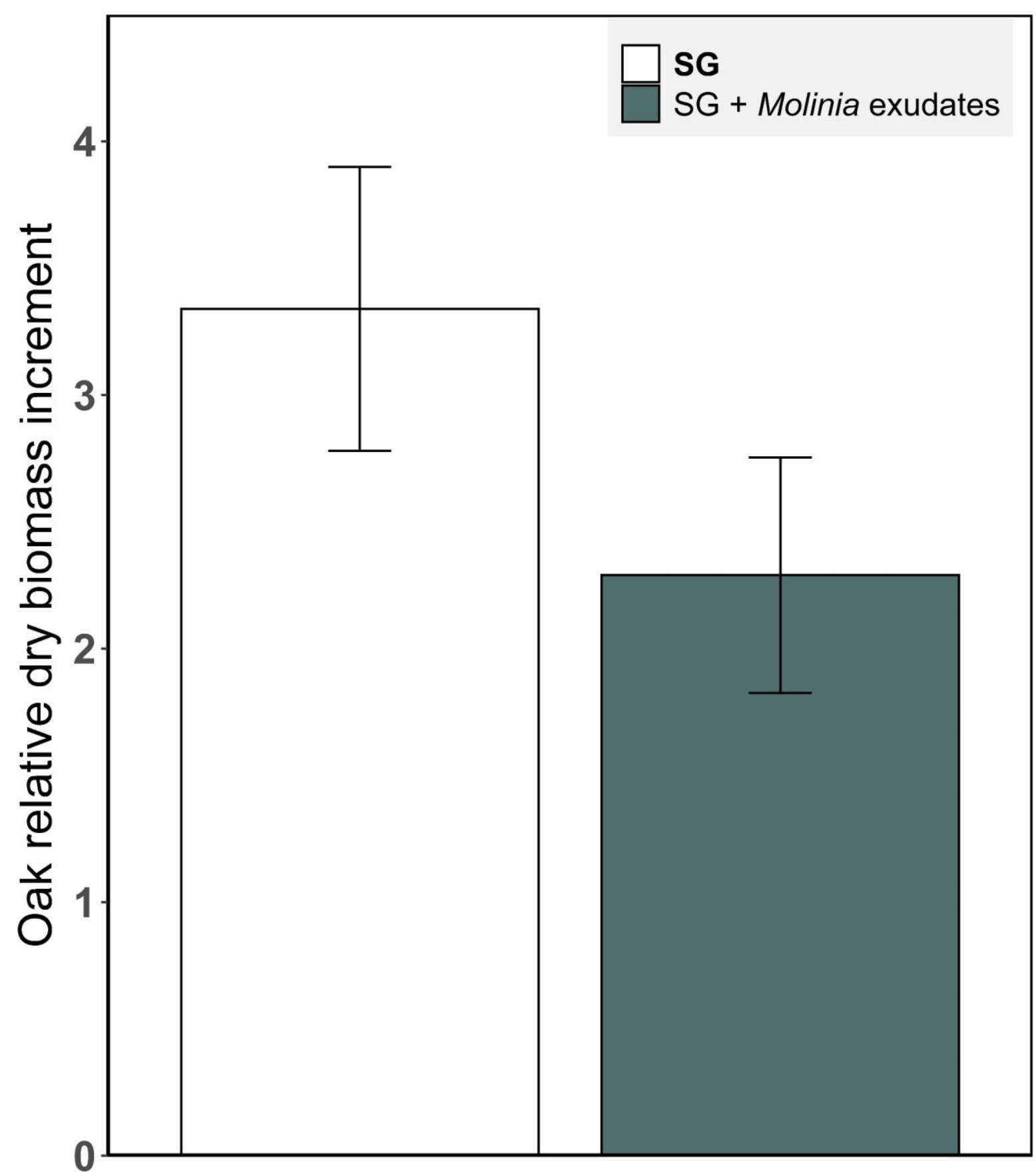


Figure 6.

One-way experiment

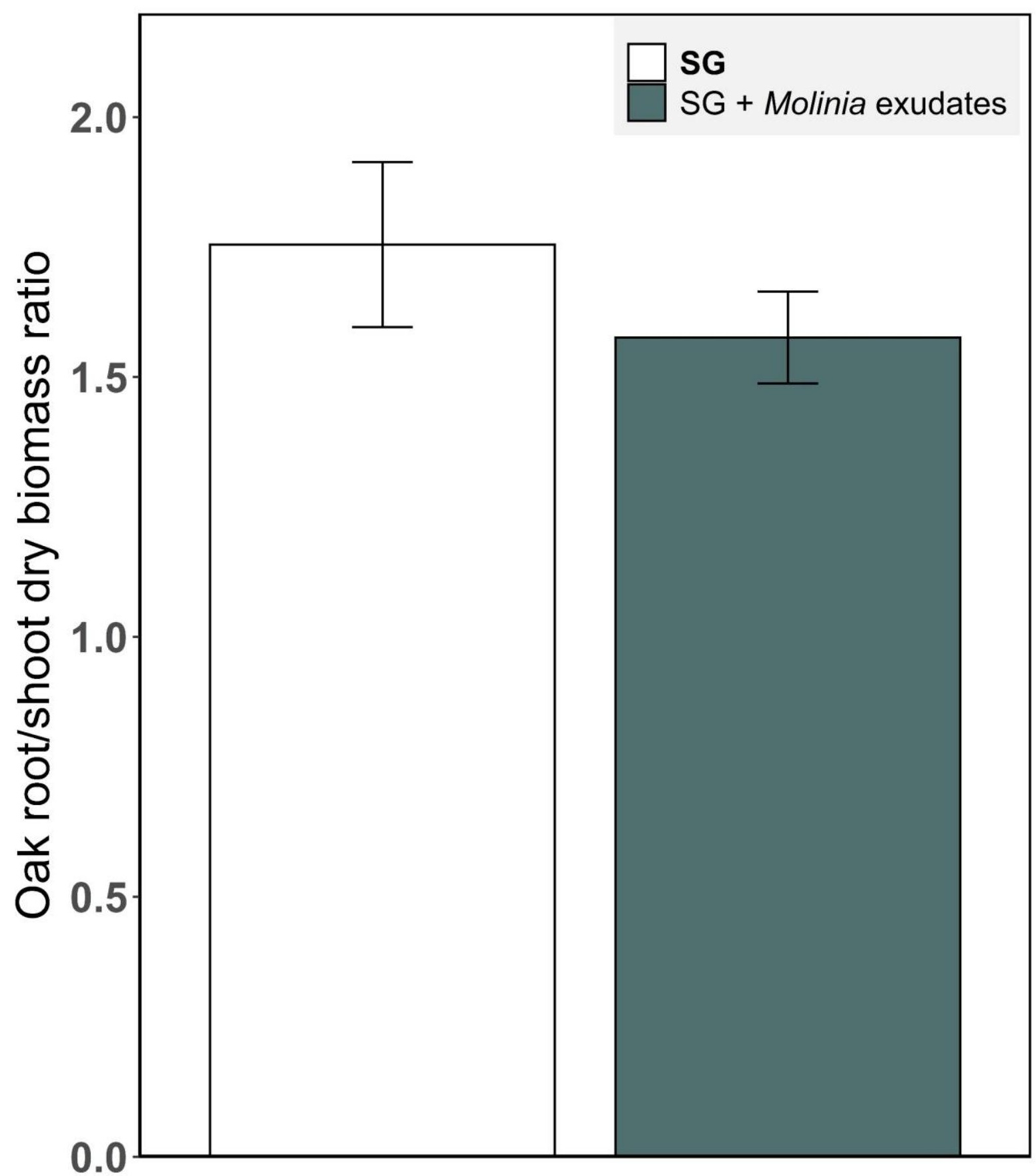


Figure S1

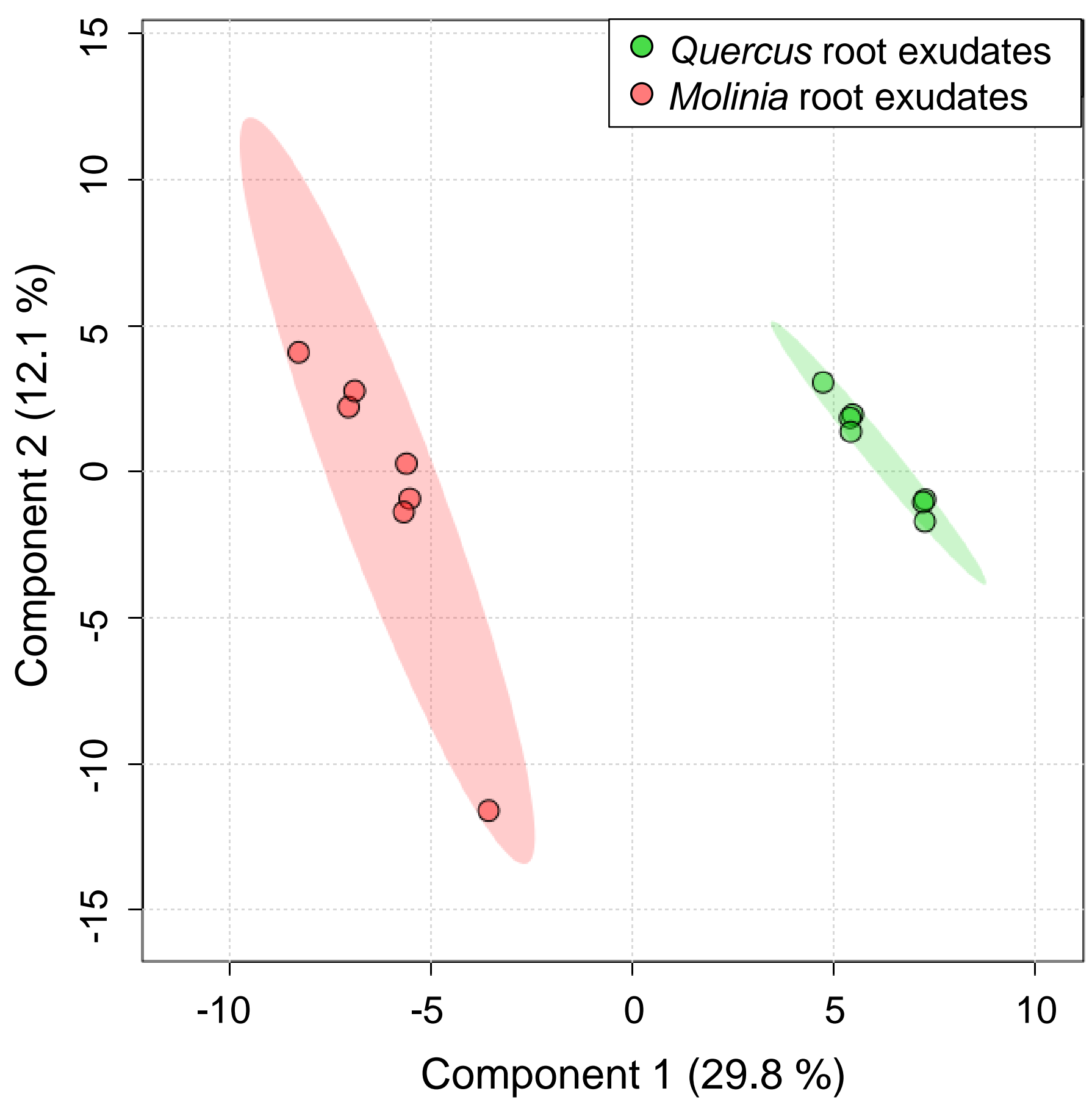


MF: Conceptualization; Data curation; Formal analysis; Methodology; Writing - original draft; review \&editing.

PM, TA, PB: Conceptualization; Formal analysis; Funding acquisition; Methodology; Project administration; Supervision; Validation; Writing - review \&editing.

CF, CG, AV: Formal analysis; Methodology; Software; Validation; Writing - review \&editing. 